\title{
CONCEPTUAL STUDY OF THE RETROFIT FOR THE CARAJAS IRON RAILROAD DIESEL ELECTRIC LOCOMOTIVES TO OPERATE IN DUAL MODE
}

\author{
Victor Leone de Oliveiraa, Pedro César Pereira Gonçalves ${ }^{b}$, Gustavo Augusto \\ Mendanha Gurgelc, Amélio Luiz Mandellid, Marcos Tavares Ronzanie, Lilian Lefol \\ Nani Guarieirof. \\ a Chemistry Department, Federal University of Ouro Preto, Brazil, \\ ${ }^{b}$ BU Drilling and Blasting, Hexagon Mining, Brazil, \\ c Engineer Department, Komatsu Mining Corporation, Brazil, \\ a Powershift, VALE, Brazil, \\ e Strategy, VALE, Brazil, \\ f University Center SENAI CIMATEC, Brazil
}

\begin{abstract}
In the recent years, VALE committed to achieve a cleaner and renewable company activity by aligning itself with the "Sustainable Development Goals" agenda, established by the UN in 2015 and aiming at sustainability goals for the year 2030 . One of the initiatives includes the electrification of the Carajas Iron Railroad (EFC). This paper discusses concepts that were developed after extensive operation data analysis and discussions with VALE's collaborators. The ideas summarized could be part of the solution towards achieving the electrification of the Carajas Iron Railroad through the implementation of catenaries in the Açailândia Hills sector and the retrofit of the diesel electric locomotives to operate in dual mode or hybrid traction.
\end{abstract}

Keywords: VALE; Locomotives; Dual-mode; Electrification; Hybrid.

\section{ESTUDO CONCEITUAL DO RETROFIT DAS LOCOMOTIVAS DIESEL- ELÉTRICAS PERTENCENTES A ESTRADA DE FERRO CARAJÁS PARA OPERAR EM MODO DUAL.}

Resumo: Nos últimos anos, a VALE comprometeu-se a alcançar uma atividade empresarial mais limpa e renovável, alinhando-se à agenda de "Objetivos de Desenvolvimento Sustentável", estabelecida pela ONU em 2015 e visando as metas de sustentabilidade para o ano 2030. Uma das iniciativas inclui a eletrificação da Ferrovia de Carajás (EFC). Este artigo discute conceitos que foram desenvolvidos após uma extensa análise de dados operacionais e discussões com os colaboradores relacionados à VALE. As ideias reunidas podem ser parte da solução para a eletrificação da Ferrovia de Carajás, através da implementação de catenárias no setor das Colinas de Açailândia e da modernização das locomotivas a diesel para operar em modo dual ou tração híbrida.

Palavras-chave: VALE; Locomotivas; Modo dual; Eletrificação; Híbrido. 


\section{INTRODUCTION}

Vale incorporates as a mission, the alignment of the company's activities with the agenda of the "sustainable development goals" established by the UN in 2015, aiming at the year 2030 [1]. Such initiative includes projects about energy efficiency, electrification of mines and railways, use of alternative fuels for transportation and pelletizing processes and use of renewable energies. [2].

In the context of reducing carbon dioxide equivalent (CO2e) emissions, Vale, based on the "Paris Agreement", committed to a $33 \%$ reduction in emissions by the year 2030, based on reference year 2017, in which the company's total emissions (in scope 1 and 2) added an equivalent of 14.1 million tons $\mathrm{CO} 2 \mathrm{e}$ whereas there is also a long-term ambition to reduce scope 3 emissions controlled by the company that were estimated at 563 million tCO2e in 2019 [3].

A great part of the energetic expenditure is due to the diesel consumption in the operations of the mine trucks and locomotives involved in the daily transportations [4]. According to VALE's 2019 Sustainability Report, 10\% of VALE's total global emissions belong to the railway transportation sector with the Carajás Iron Railroad accounting for nearly $70 \%$ of the CO2e emitted by the sector [5].

For this reason, projects and studies that reinforce the electrification of the railway operations are part of the company's initiatives since the energy transition by means of electrification can both provide a cleaner and potentially cheaper operation, but also a measure to adapt for stricter environmental regulations [6-7].

The Electrification could be carried out by overhead contact lines or by using the third rail [8]. Several reasons like cheaper operational and maintenance cost, safety and security concerns favors the preference of overhead lines for long distances railways even if there is a great capital expenditure associated with the construction of the electric network and the adaptation of the current infrastructure [9]. Also, regarding the rolling stock, the use of overhead lines would imply the need to upgrade the locomotives either by replacing the diesel electric for new electric ones or by retrofitting the current locomotives.

In this scenario, the retrofit of diesel electric locomotives to operate in dual mode using either the diesel or electricity provided by overhead lines allow various benefits such as the possibility of a gradual installment of the electric network, reuse of the current owned rolling stock and the extension of its useful life [10]. The hybrid locomotives, on the other hand, can bring benefits such as the reduced retention and shunting time, improved flexibility, higher reliability as they can operate using two types of fuels and finally, the reduction of the greenhouse gases emission [11].

\subsection{Carajas Iron Railroad Electrification}

The Carajás Railway (EFC) has an extension of approximately 980 kilometers, consisting of 4 tunnels and 62 bridges or pedestrian bridges with 80 percent of duplicated line and the gauge characterized by the width of $1600 \mathrm{~mm}$. The line is divided into 6 sectors that start in the province of Carajás, in Pará, interconnecting with the port of Ponta da Madeira, in São Luís in Maranhão [12]. 
On the Carajás Railway, the highest point of the trip is located between the Alto Alegre stretches and the Açailândia yard, on the Açailândia Hills sector which persists for approximately 130 kilometers over a distance of 300 to 500 kilometers from the Carajás mine. During the transposition of the stretch, two additional locomotives, called 'helpers', are coupled to the moving train so that the consist has enough energy to overcome the two up hilled paths [13].

The altimetry in Figure 1 illustrates the stretch of dynamic helpers in Açailândia, divided into two slope sectors (300 - $350 \mathrm{~km}$ and $380-440 \mathrm{~km}$ ) totaling 110 kilometers. In an annual perspective of EFC operations, diesel consumption only in the Açailândia section is of 85 million liters of diesel. The elimination of fuel burning in this stretch by electrification and subsequent retrofit of the fleet's locomotives for dual-mode operation would represent a 1.59\% decrease in Vale's total emissions and an impact of $4.82 \%$ company goal defined by the Paris Agreement [14].

Figure 1. Altimetry Profile of the Carajas Iron Railroad.

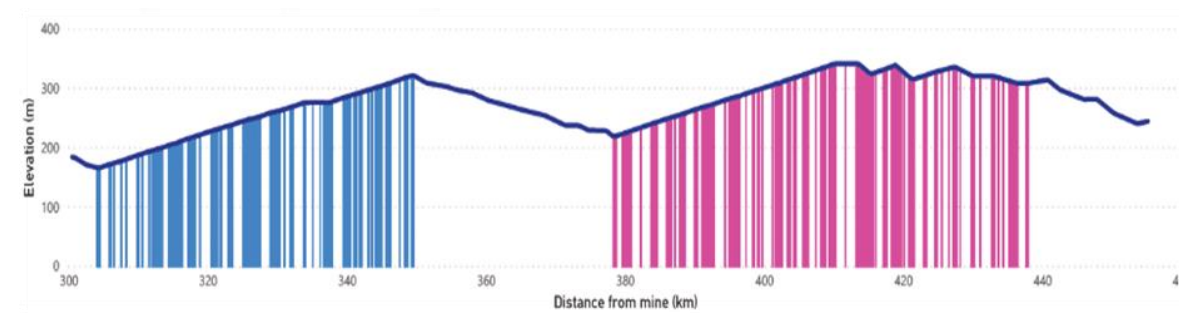

According to VALE's roadmap developed by its Powershift department, one of the most important steps to achieve the energetic transition into the upcoming decade is the electrification of the Açailandia Hills located in the Carajas Iron Railroad (EFC). Therefore, this study aims to investigate the technical feasibility of retrofit for the diesel electric locomotives of the EFC's Fleet to operate in dual mode using either the energy from the catenaries or the diesel on the non-electrified sectors.

\section{METHODOLOGY}

Initially, the study was conducted using data available in the literature, public sources and information acquired through contacts made with the logistic, operational and Powershift sector. After obtaining basic knowledge of the railroad infrastructure, Vale granted access to the event recorder from the month of May of the year 2019 onwards for three compositions of consists that are operated on the EFC. A spreadsheet was organized with all information, inference results and studies on the subject.

About three million lines of data were analyzed, allowing for insights of the traction effort along the stretch as well as the use of acceleration points, point to point distributed throughout the EFC. Through this information, it was further analyzed the operations within the maneuvering yards and the information on fuel consumption by the locomotives.

Subsequently, the acquisition of historical data allowed the modeling of the profile of EFC consumption through Business Intelligence platform - Power BI Desktop 
software provided by Microsoft. In order to display information received and make operational understanding more agile about types of traction, the data was organized by temporal analysis of information regarding fuel consumption, stratification of the number of trips, loading, transportation time and throttle. Concepts were discussed with VALE's collaborators which would enable the retrofit of the locomotives and the electrification of the EFC.

Data regarding fuel operation and consumption were analyzed for each type of consist (AC, DC and Mixed), in order to understand the possible impacts and identify bottlenecks. The helper's locomotive data were also analyzed, considering that they can be moved for cargo transportation operation.

For the development of the conceptual study, the DASH 9-40BBW and EVO ES58ACl were chosen as the models to be investigated, as they totalize 183 locomotives in the EFC, approximately $60 \%$ of the fleet. In addition, both locomotives have the same dimensions in height and width, with a variation in relation to the total length. Therefore, they offer a representative sample of the minimum power, energy and dimensions requirements for the retrofit of the entire fleet (283 locomotives and 7 models).

The retrofit study was based on the feasibility analysis of three concepts mainly focused on the generation or reuse of spaces in the current chassis configuration to install the additional equipment needed for retrofit: (1) Reduction of the Diesel Tank; (2) Use of an extra component wagon; (3) Use of free space in the cabins of autonomous locomotives.

\section{RESULTS AND DISCUSSION}

\subsection{Reduction of the Diesel Tank}

In the scenario of overhead contact lines implementation, the reduction in fuel consumption gives opportunity to reduce the diesel tank in order to accommodate the new electrical components to be installed such as the transformers. The data analysis of the energetic profile of the EFC reveals that the electrification of the Açailândia Hills sector would reduce the overall diesel consumption by $25 \%$. Comparing the measurements of the commercially available transformers used for heavy haul electric locomotives, a length reduction of $35 \%$ would be necessary to generate enough space in order to install the transformer beneath the locomotive's chassis.

Figure 2. Dimensions of the DASH 9-40BBW diesel tank (a) and EVO ES58ACI (b).

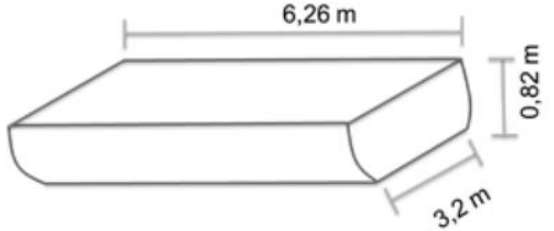

(a)

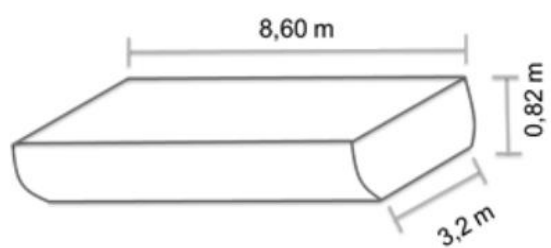

(b)

Source: General Electric's Technical Drawing [15]. 
The current dimensions of the diesel tank for each model, Dash-9 with capacity to $18000 \mathrm{~L}$ and Evo with a capacity of $23000 \mathrm{~L}$, are illustrated at Figure 2.

The potential for reducing the diesel consumption for a single trip and consequently, the potential for reduction of the diesel tank dimensions were calculated under four scenarios: (1) The installment of the catenaries - overhead lines at the Açailândia Hills Sector (OLE); (2) The presence of the catenary plus a throttle balance allowed only in the electrification scenario(OLE $+T B)$; (3) The presence of the catenary plus a second refueling point at Marabá (OLE + QMA) ; (4) The presence of the catenary plus a throttle balance and a second refueling point (OLE + TB + QMA). The results are shown in Table 1.

Table 1. Potential of the diesel tank dimensions versus hypothesis

\begin{tabular}{|l|c|c|c|}
\hline & Consist (AC) & Consist (DC) & Consist Mixed \\
\hline OLE & $19,3 \%$ & $29,9 \%$ & $15,5 \%$ \\
\hline OLE + TB & $33,6 \%$ & $38,4 \%$ & $30,2 \%$ \\
\hline OLE + QMA & $45,5 \%$ & $56,2 \%$ & $43,8 \%$ \\
\hline OLE + QMA + TB & $63,6 \%$ & $67,1 \%$ & $62,5 \%$ \\
\hline
\end{tabular}

\subsection{Extra component electric wagon}

The difficult to install new components on the locomotive and accomplish the retrofit is caused by the restrictions of the external gauge represented by tunnels, bridges, car dumpers and silos or the internal tight space. Therefore, it is necessary to think of an alternative concept for the use of energy from catenary, without the installation of new components in the locomotives. The idea of an extra wagon is based on the combination of a diesel-electric locomotive to be modified and the presence of a wagon to be developed that serves as both a power source and an electrical component carrier [16].

The concept is an option of barely no interference to the existing locomotives, resulting in the need for retrofit aiming only at the standardization of the coupling between the components and the locomotive. Finally, the construction of these wagons brings more flexibility to the project, since it is completely modular [17]. There is also the possibility of further evolution by adding batteries, which could generate power for traction and/or auxiliary system, reaching a greater reduction of pollutant gas emissions [18].

Despite the flexibility of this concept, there are impacts that must be observed in the consist operation and composition, such as added weight and impacts during the trip (Transit Time).

Weight cannot be added to the current consist, and as the removal of wagons must be done in pairs, the addition of an extra component wagon of components would mean a minimal loss of 6 to 8 wagons per consist, resulting in a total loss of 3.65 million 
tons of iron per year to the current hauling capacity and an addition of approximately 106 consists to maintain the same productivity, based on 2018 production data. This would cause an increase in fuel consumption by 6.85 million liters.

Finally, despite the scenario of a $25 \%$ reduction in consumption and emissions with the installation of catenaries, the use of extra component wagons could reduce the estimated gaseous emission reduction to 23.5 percent if the individual weight of the components does not exceed the total weight of 250 tons (two wagons loaded with iron ore).

\subsection{Reuse of the operator's compartment in autonomous locomotives}

The study of this concept is justified for two reasons. First, the use of this technology tends to be greater in the upcoming decades, according to the performance benefits that an automation brings [19]. Therefore, it is necessary to evaluate alternative modernization or customizations that meet VALE's requirements, including requests to reduce gaseous emissions. The second reason stems from the fact that with the exception of the first locomotive that pulls the consist, all other locomotives work by remote control.

Currently, the cabin has the space and set of equipment conditioned to the presence of the operator. For autonomous locomotives (stage 4) or semi-autonomous (remote control), the necessity of both are eliminated. Therefore, the cabin space may undergo readjustments after using equipment which are required for a dual-mode operation.

In Figure 3, the basic layout of the cab for the locomotives used as models for this study is displayed. The following equipment, which are highlighted by a grey frame are associated with the operator and are only there for his needs: air conditioning and heating, refrigerator, chair, control panel lower devices, engine device control panel and device panel crew technicians.

Figure 3. Current Cab's layout.

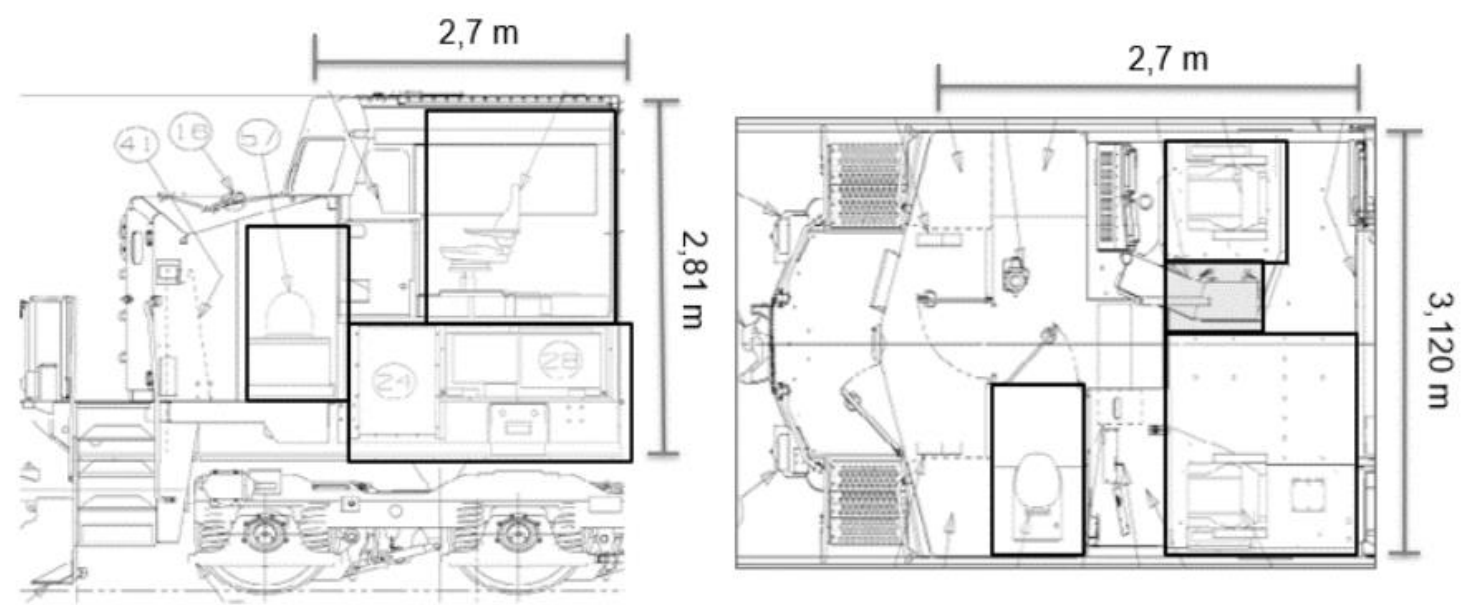

Source: General Electric's Technical Drawing [15]. 


\section{CONCLUSION}

The present study included an analysis of conceptual feasibility for the electrification of the Açailândia section on the Carajás Railway (EFC), a high energy demand part of the track. The investigation conducted for the elaborated concepts, focused on the technological readiness, the potential savings in the transition of the energy matrix, impacts on the operation and emissions of CO2e. For some of the analyzes, access to Vale's infrastructure for modeling data and simulation of operations would bring more consolidated conclusions about the potentiality of the concept. In other cases, research and additional prospecting with the railway sector companies will be necessary to obtain better estimates, mainly in relation to implementation costs. This greater robustness of information will be necessary for the decision-making targeting the electrification concept that will be taken forward to stakeholders in a future request for quotation procedure.

\section{Acknowledgments}

The authors wish to extend their gratitude to VALE, the Massachusetts Institute of Technology, the Imperial College, the SENAI CIMATEC, The Bakery and to all partners of the Mining Innovation for a New Environment (MINE) program.

\section{REFERENCES}

1VALE. POL-0012-G - Política de Mitigação e Adaptação às Mudanças. DCA 100/2012. 2012, 3 p.

${ }^{2}$ GOÉS, Francisco; Rosas, Rafael. Vale terá US\$ 2 bilhões para reduzir emissões. Econômico Valor. 2020 . Available at: <valor.globo.com/empresas/noticia/2020/05/13/vale-tera-us-2-bilhoes-para-reduziremissoes.ghtml>. Accessed on: 18 May. 2020.

${ }^{3}$ VALE. Meio Ambiente. Mudanças Climáticas. 2019. Available at: $<$ vale.com/esg/pt/Paginas/MudancasClimaticas.aspx>. Accessed on 14 Apr. 2020.

${ }^{4}$ VALE. Consumo: Reporte de KPIs. 2015. Available at: $<$ vale.com/PT/business/energy/consumo/Paginas/default.aspx>. Accessed on 15 Feb. 2020.

${ }^{5}$ VALE. Sustentability Report 2019. Execution by Institutional Relations, Sustainability and Communication Board. 2020, 136 p.

${ }^{6}$ VALE. Vale e Progress Rail desenvolvem primeira locomotiva $100 \%$ elétrica da mineração brasileira. Sobre a Vale. 2020. Available at: $<$ vale.com/brasil/PT/aboutvale/news/Paginas/vale-e-progress-rail-desenvolvemprimeira-locomotiva-100-eletrica-da-mineracao-brasileira.aspx>. Accessed on 29 July. 2020. 
${ }^{7}$ ZENITH, Federico. Et al. Techno-economic analysis of freight railway electrification by overhead line, hydrogen and batteries: Case studies in Norway and USA. Journal Rail and Rapid Transit, v. 234, n. 7, p. 791-802, 2019.

8YADAV, Aníl. Traction choices: overhead ac vs third rail dc. International Railway Journal. 2013. Available at: <https://www.railjournal.com/in_depth/traction-choicesoverhead-ac-vs-third-rail-dc>. Accessed on 16 Feb, 2020.

${ }^{9}$ BAXTER, Alan. Network Rail A Guide to Overhead Electrification. United Kingdom. 2015. Available at: <bathnes.gov.uk/sites/default/files/sitedocuments/Planning-andBuilding-Control/Planning/nr_a_guide_to_overhead_electrification.pdf $>$. Accessed on 17 Feb. 2020.

${ }^{10}$ MECA. Manufacturers of Emission Controls Association. Case Studies of the Use of Exhaust Emission Controls on Locomotives and Large Marine Diesel Engines. United States of America. 2006. Available at: $<$ meca.org/galleries/files/MECA_locomotive_and_marine_case_study_report_1006.p df>. Accessed on 18 May. 2020.

${ }^{11}$ RDSO. Research Designs \& Standard Organization. Specification for dual mode Passenger Locomotive. Specification: $\mathbf{N}^{\circ}$ MP 0.0800-108. 2015, 23 p.

${ }^{12}$ ANTT. NACIONAL TERRETRIAL TRANSPORT AGENCY. Concessões Ferroviárias. Available at: <antt.gov.br/concessoes-ferroviarias>. Accessed on 28 May. 2020.

${ }^{13}$ PEREIRA, Olyntho Carmo. Soluções de otimização da eficiência energética de uma ferrovia de carga: o caso da estrada de ferro carajás. 2009. Thesis (Master's degree in Production Engineering) - Pontifical Catholic University of Rio de Janeiro. Rio de Janeiro, 2009.

${ }^{14}$ VALE. Carajas Iron Railroad Event Register from the year of 2019. Excel (2013). Belo Horizonte, 2020.

${ }^{15} \mathrm{GE}$. General Electric Company. Technical Drawing of ES58ACI. 2010.

${ }^{16}$ SUDOSTBAYERNBAHN. Südostbayernbahn gewinnt ERCI Innovations Award. 2018. Available at: <suedostbayernbahn.de/so_bayern/view/aktuell/news/erciinnovationsaward.shtml>. Accessed on 13 Jun, 2020.

${ }^{17}$ GE. General Electric Company (United States). Ajith Kuttannair Kumar. Hybrid energy locomotive electrical power storage system. US n. 2002/0174798A1. 28 Nov. 2002, 26 Dec. 2021.

${ }^{18}$ Bombardier Transportation $\mathrm{GmbH}$. Ludwig Still. Circuit for supplying electric energy in a rail vehicle, from a supply network or from an engine generator. EP 2396188B1. 21 Dec. 2018, 11 Feb. 2030.

${ }^{19}$ MARKETS AND MARKETS. Autonomous Train Market. Markets and Markets. 2018. Available at: <marketsandmarkets.com/Market-Reports/autonomous-trainmarket-27451077.html>. Accessed on: 27 May. 2020. 